\title{
The Efficiency of the Online Academic Teaching Process During the Pandemic Covid-19
}

Horia Mihai Raboca, Daniela Cotoranu 


\title{
The Efficiency of the Online Academic Teaching Process During the Pandemic Covid-19
}

\author{
Horia Mihai Raboca ${ }^{a}$, Daniela Cotoranu ${ }^{b}$ \\ ${ }^{a}$ Faculty of Political, Administrative and Communication Sciences, Babeș-Bolyai University, 1 Mihail Kogalniceanu Street, Cluj-Napoca, 400000, \\ Romania \\ ${ }^{b}$ Doctoral School of Administration and Public Policy, Faculty of Political, Administrative and Communication Sciences, Babeș-Bolyai University, 1 \\ Mihail Kogalniceanu Street, Cluj-Napoca, 400000, Romania \\ *Corresponding author: raboca@fspac.ro
}

\section{Abstract}

\section{Keywords:}

online academic teaching process, educational efficiency, barriers, pandemic Sars COV-2, performance
This article aims to identify the efficiency of the online academic teaching process during the Sars COV- 2 pandemic, but also identify the main factors which negatively influence the online academic teaching process. The study is based on quantitative research, the data of which were collected by applying an online questionnaire to students at the Faculty of Political, Administrative and Communication Sciences in ClujNapoca between 01.06.2020-01.07.2020.

The results of the study indicate that, during the pandemic, the efficiency of the online teaching process is below the level of the classic teaching process and is negatively influenced by a number of factors (lack of knowledge and technical information held by students / teachers on online teaching platforms, resistance to change of students / teachers (fear of something new (scary) - feeling rejected by the new because you think you can't cope or may have negative effects or repercussions for you, etc.). However, in order for the online teaching process to be successful, a greater importance should be given to the transfer of responsibility process: focusing on the individual learning process or on the continuous improvement of the online academic teaching process. This transfer can lead inherently and implicitly to an increase in the degree dissatisfaction.

\section{Zusammenfasung}

\section{Schlüsselworte:}

akademischer Online-

Unterrichtsprozess, Bildungseffizienz, Barrieren, Sars COV-2Pandemie, Leistung
Dieser Artikel zielt darauf ab, die Effizienz des Online-Unterrichtsprozesses während der Sars COV-2-Pandemie zu ermitteln, aber auch die Hauptfaktoren, die den Online-Unterrichtsprozess negativ beeinflussen. Die Studie basiert auf quantitativer Forschung, deren Daten durch Anwendung eines Online-Fragebogens an Studenten der Fakultät für Politik-, Verwaltungs- und Kommunikationswissenschaften in Cluj-Napoca zwischen dem 01.06.2020 und dem 01.07.2020 erhoben wurden.

Die Ergebnisse der Studie zeigen, dass während der Pandemie die Effizienz des Online-Unterrichtsprozesses unter dem Niveau des klassischen Unterrichtsprozesses liegt und durch eine Reihe von Faktoren negativ beeinflusst wird (mangelndes Wissen und technische Informationen der Studenten / Lehrern auf OnlineUnterrichtsplattformen, Widerstand gegen Veränderungen von Schülern / Lehrern (Angst vor etwas Neuem (beängstigend) - Gefühl, von Neuem abgelehnt zu werden, weil Sie glauben, dass sie nicht damit umgehen können oder dass es negative Auswirkungen auf sie haben können usw.) Damit der Online-Unterrichtsprozess erfolgreich ist, sollte dem Prozess der Übertragung von Verantwortung eine größere Bedeutung beigemessen werden: Konzentration auf den individuellen Lernprozess oder auf die kontinuierliche Verbesserung des Online-Unterrichtsprozesses. Dieser Transfer kann inhärent und implizit zur Steigerung der Unzufriedenheit führen.

\section{Introduction}

Educational institutions in both Romania and worldwide are currently facing one of the biggest crises in the education system generated by the emergence of the SARS COV 2 virus, which involved the transition from a classic teaching system to one exclusive online.

The online academic teaching process can be considered a real challenge in Romania, because there is still needed a much more in-depth training on how to conduct online courses, there are still major discrepancies at national level regarding the access to Internet and devices necessary to support a new teaching style, the possession of such a device by each student being crucial during the maintenance of the online teaching process during the pandemic. However, the question would be, how efficient is this style of teaching compared to the classic teaching process in Romania?

Thus, this research aims to analyze how the process of online academic teaching is defined in specialized studies and to identify the efficiency of the online academic 
learning process from the students' perspective, as well as identifying the main barriers to the online academic teaching process.

Also, the research is based on data from the analysis of other specialized research, as well as data obtained by conducting a sociological analysis that consisted of applying online questionnaires to students at the Faculty of Political, Administrative and Communication Sciences, Cluj-Napoca, to determine the level of educational efficiency from their perspective.

The online teaching process is considered to be effective, but at the same time it involves a series of challenges to which educational institutions and students must adapt. According to a study, the main challenges involved in the transition to online academic teaching are mainly related to "connectivity issues, lack of infrastructure and costs, while in Asian countries such as India and China the challenges of financial costs, regulations predominate and the digital divide, while European universities face a lack of students' self-motivation skills" (Amemando, 2020).

In contrast, as educational institutions have begun to adapt and digitize their courses, they have failed to deliver quality learning such as classical teaching and have placed more emphasis on providing high quality online platforms to demonstrate that they can be competitive (Michie, 2020).

Following the study of the concept, a significant difference was observed regarding the use of the online academic teaching process during the pandemic in Romania compared to the existing studies at international level.

\section{Theoretical foundation}

\subsection{The online teaching process}

The online academic teaching process (E-learning) can be defined as a process by which teaching takes place partially or totally via the Internet, but at the national level this teaching style was not used until the global pandemic, which involved the transition from the classic teaching process in educational institutions to the entirely online teaching process.

In existing studies in the literature, online academic teaching includes a number of definitions. According to some researchers, online teaching is defined as "the process that includes learning materials that have already been converted into HTML text and graphics and that are placed on either a server or a site" (Booker,p. 4), while other researchers have defined the online teaching process as "the interaction between the teaching / learning process and information technologies - ICT (Information and Communication Technology) that can cover a wide range of teaching activities conducted entirely online" (Brut, 2006), but also as a "learning experience in synchronous or asynchronous environments that use different devices (e.g. mobile phone, laptop, etc.) with internet access" (Raboca \& Cărbunărean, 2015).
The synchronous online academic teaching process involves the participation of students in live lectures, the creation of interactions between teachers and students as well as the creation of the possibility of providing immediate feedback, while asynchronous online learning environments are not properly structured. Specifically, learning content is not available in the form of lectures or live courses but in the form of learning systems or forums / platforms (Sadeghi, 2007).

Also, the online academic teaching process is defined as "a teaching / learning activity planned by an institution that provides educational resources stored on electronic media in a sequential and logical order to be assimilated by students in their own way, without forcing you to synchronize group activities.

On the other hand, online teaching was defined as "a teaching method that capitalizes on the principles of modeling and analysis of training activities in the context of the use of information and communication technologies, characteristic of contemporary society" (Adăscăliței, 2007), but also as "a training that takes place through a computer connected to a network, the educational content can be in the form of a traditional lesson or a collaborative work session, made with the help of communication technologies. Educational materials can be presented in the form of text, graphics, audio and video materials" (Moise, 2008).

Following these definitions, it can be said that the online teaching process is a teaching style that involves the use of electronic devices and connection to various platforms through which the learning process is facilitated and participation in courses doesn't require presence in classrooms.

Currently, the online teaching process is the only option through which students can continue their studies, but the studies show that, although online teaching can be used in times of crisis, it is recommended that the educational institutions assess the situation very well and ensure that they can support the online teaching process, before resorting to online teaching. (Cho \& Shim, 2013).

With the implementation of the new measures taken by the central public authorities during the SARS-COV2 pandemic, each educational institution had to adapt to the online teaching and learning process, but at national level have been identified a series of barriers faced by the educational system. One of the main factors that can influence the online teaching process is the lack of socialization, the interaction between students, and studentteachers. According to a study, the main barriers in online learning from the perspective of students refer to: "administrative problems, lack of social interaction, academic and technical skills, student motivation, time and support in online learning, costs and internet access, but also connectivity related issues" (Muilenburg et.al., 2007).

Although technology has improved significantly and we have access to a number of applications / platforms that 
can facilitate the online academic teaching process, there are a number of factors that can negatively influence the online academic teaching process during the pandemic: "download errors, problems with installation, connection, audio and video issues, etc. which may occur, but also the lack of attention and commitment from students and the lack of e-learning skills of students / teachers "(Dhull \& Sakshi, 2017).

Also, the lack of control over students during exams, the lack of motivation from students, which are easily distracted from anything else, only by active participation in classes not, and the lack of feedback ("students tend to be dissatisfied with the lack of rapid feedback, and because of this, teachers are forced to find alternative methods to improve feedback" (Tamm, 2019) are other factors that negatively influence the online teaching process.

Uncertainty may be the one that can describe the faculty's perception of online education during the SARSCOV2 pandemic, because the measure of moving from the classical teaching process was imposed by law, a process that was very well established, structured, in which barriers were kept under control, control constantly aiming at increasing the educational performance and efficiency, to a completely online teaching process, a totally new process in the Romanian educational system.

Table 1. The main barriers identified in specialized studies

\begin{tabular}{|l|l|l|}
\hline Concept & \multicolumn{1}{|c|}{$\begin{array}{l}\text { The main barriers identified in } \\
\text { specialized studies }\end{array}$} & Authors \\
\hline $\begin{array}{l}\text { The online } \\
\text { teaching } \\
\text { process }\end{array}$ & $\begin{array}{l}\text { "Lack of feedback, lack of } \\
\text { motivation of students, lack of } \\
\text { efficiency of teacher control } \\
\text { during exams." }\end{array}$ & $\begin{array}{l}\text { Tamm, } \\
2019 .\end{array}$ \\
\hline $\begin{array}{l}\text { The online } \\
\text { teaching } \\
\text { process }\end{array}$ & $\begin{array}{l}\text { "Administrative problems, lack of } \\
\text { social interaction, academic and } \\
\text { technical skills, student } \\
\text { motivation, time and support } \\
\text { provided in online learning, costs } \\
\text { and internet access, but also } \\
\text { problems related to connectivity." }\end{array}$ & $\begin{array}{l}\text { Muilenbu } \\
\text { rg et.al., }\end{array}$ \\
\hline $\begin{array}{l}\text { The online } \\
\text { teaching } \\
\text { process }\end{array}$ & $\begin{array}{l}\text { "Problems related to connectivity } \\
\text { and internet access, lack of } \\
\text { technological } \\
\text { financial costs". }\end{array}$ & $\begin{array}{l}\text { Sadeghi, } \\
2007 .\end{array}$ \\
\hline $\begin{array}{l}\text { The online } \\
\text { teaching } \\
\text { process }\end{array}$ & $\begin{array}{l}\text { "Lack of interaction between } \\
\text { students, teacher-students, high } \\
\text { costs of purchasing software and } \\
\text { hardware". }\end{array}$ & $\begin{array}{l}\text { Harper } \\
\text { et. al, }\end{array}$ \\
\hline $\begin{array}{l}\text { The online } \\
\text { teaching } \\
\text { process }\end{array}$ & $\begin{array}{l}\text { "Lack of organizational culture, } \\
\text { lack of technical skills, lack of } \\
\text { knowledge and training on online } \\
\text { platforms". }\end{array}$ & $\begin{array}{l}\text { Holt et. } \\
\text { al., 1998. }\end{array}$ \\
\hline
\end{tabular}

\subsection{Educational efficiency}

The first part of this article analyzed what the online academic educational process is and identified the main barriers encountered in the online teaching process, and in this part of the study we will focus on defining the concept of educational efficiency.

Most of the time, educational efficiency is misunderstood, and some studies show that, "the efficiency of the educational process is an objective that should be pursued by all educational institutions", but, on the other hand, there are other studies that come and contradict this statement, indicating that "efforts to achieve the highest possible educational efficiency, will undermine exactly what is at the heart of the educational process", this situation is determined by the misunderstanding of the meaning of efficiency (https://education.stateuniversity.com).

At the moment, there is a high emphasis on the efficiency of the educational process in order to develop professional skills, especially in higher education institutions. The literature suggests that the efficiency of the online teaching process in higher education is influenced by a number of factors such as: "the ability to effectively organize online teaching activities, how to teach, and testing and monitoring the intelligibility of educational material" (Nikolaenko et.al, 2016).

Educational efficiency is defined by some researchers as "a specific set of resources with a positive effect on the quality of teaching and learning" (Lockheed \& Hanushek, 1994), while other authors believe that educational efficiency can be defined as "a comparison of inputs and related outputs" (Hanushek, 1986), or as "the degree to which certain pedagogical practices or school pathways affect or not the learning" (Psacharopoulos \& Loxley, 1985).

A study of students at the University of Information Technology (CUIT) in Chengdu, China, identified the students' perceptions of online academic teaching during the COVID-19 situation, the effectiveness of online courses, and whether the process an online questionnaire was applied to students in undergraduate engineering specializations to achieve the objectives of the study. The results of the study showed that the results regarding the efficiency of online courses are more than depressing, only $25.5 \%$ considered the online courses to be effective and useful, whereas in terms of comparing teaching styles (online versus classical) only $34.6 \%$ of participants preferred the online teaching process. It was possible to analyze the degree of attention of the students during the online courses the results indicate that over $60 \%$ of students are attentive in the first 15 minutes and that after 25 minutes from the start of the online course about $20 \%$ remain focused and not distracted and generally they are dissatisfied with the learning effect online (Radha et. al., 2020). As can be seen, the sudden shift from a classic teaching style to an exclusively online one has led to a number of challenges among students and teachers, with some studies claiming that the online teaching process can be effective, while others Studies show that students 
quickly lose patience during online courses, and the effectiveness of online courses is much lower than that obtained from face-to-face courses.

\subsection{Forms of teaching during a pandemic}

The negative effects generated by the pandemic determined the approach of three major forms (scenarios) of teaching that could be adopted depending on the extent of the pandemic, these being both advantages and disadvantages. Thus, one of the pandemic teaching scenarios is the hybrid teaching process, which however is the most difficult to implement, but offers a number of advantages. The hybrid teaching process is necessary to be used for technological specializations, medicine, more precisely where it is necessary to carry out experiments, laboratories, specialized practice.

One of the advantages offered by this scenario is the maintenance of teacher-student interactions, face-to-face communication, allows or directly involves, etc., but has as main disadvantage the high costs, the lack of organization and management of schools and the lack of organization of students.

Regarding the classical teaching process, it offers the possibility of holding face-to-face courses, which determines a direct communication and interaction, teaching material can be easier to assimilate, efficient and the quality of the classical teaching process are high, but has the disadvantage of high costs for ensuring and respecting the conditions of social distancing. Thus, the most efficient form of teaching during a pandemic can be considered an online academic teaching process, it involves lower costs than the classic process, it is much more flexible and accessible compared to the classic teaching process, allows monitoring and evaluation, manual or automatically, the results obtained by students, as well as activity during courses / seminars, and as a disadvantage of the online teaching process is spending a large number of hours in front of the computer, possible issues at connecting / using online platforms, the digital divide, but also the lack of transmission of rigorous scientific content.

However, with the onset of the COVID-19 pandemic, the education system has had to adapt to new changes and adopt the most efficient teaching process to ensure further studies during the pandemic.

\section{Research methodology}

The purpose of the research was to find the answers to the following questions:

- In the case of the online teaching process, can we speak or not of a high degree of educational efficiency?

- In terms of educational efficiency, where is the online educational process compared to the classic (face-toface) educational process?

- What are the main factors that can negatively influence the use of the online teaching process during the pandemic?

The research objectives were:
- Investigating and highlighting, from the students' point of view, the level (degree) of educational efficiency of the online teaching process used during the pandemic period (both in general and compared to the classical teaching process);

- Investigate and highlight, from the students' perspective, the main factors that can negatively influence (reduce) the online teaching process used during the pandemic period (barriers to the use of the online teaching process).

It should be mentioned that this research is part of a larger research aimed at the impact of the pandemic generated by the appearance of SARS COV 2 virus on students, survey conducted between 01.05.202001.07.2020.

In this sense, the research was conducted on the basis of a sociological survey conducted among senior students enrolled in bachelor's and master's programs in public administration, respectively the bachelor's degree program (students in the last year of study), programs offered by the Faculty of Political Science, Administrative and Communication at Babeș-Bolyai University.

Also, the survey was conducted based on the completion of an anonymous questionnaire by students, the number of interviewees, taken in the analysis, being 193 (table 2.1.) The analysis and data processing aimed at an invariable analysis of some questions in the questionnaire. Thus, starting from the premise that educational efficiency, as a concept, can be defined as "the volume of information and knowledge acquired by a student after the teaching process, as well as the quality level of this information and knowledge", the investigation of the level of efficiency as operationalization) was carried out from the prism (perspective) of 2 dimensions, namely:

- the general level of efficiency perceived by students regarding the online educational process;

- the level of efficiency of the online educational process perceived by students compared to the classical educational process (face to face).

In order to investigate the factors that negatively influence the online academic teaching process during the pandemic, a question with a number of 9 items was used, the interviewees having to express their opinion on the extent to which the 9 items may or may not be considered barriers (negative factors) in the use of the online teaching process. The scale used is a 1-5 scale of the Likert type (1very small measure, 5 - very large).

Table 2 . The level of the study program and the specialization of the study participants

Study program level (percentage of total respondents \%)

\begin{tabular}{l|l} 
License program & $69.9 \%$ \\
\hline
\end{tabular}

\begin{tabular}{l|l}
\hline Master's program & $30.1 \%$
\end{tabular}

Specialization of study respondents (percentage of total respondents)

\begin{tabular}{|l|l}
\hline Public Administration program & $59.1 \%$ \\
\hline Adverting
\end{tabular}

\begin{tabular}{|l|l}
\hline Advertising program & $40.9 \%$ \\
\hline
\end{tabular} 


\section{Results and discussions}

Regarding the level of educational efficiency of the online academic teaching process, the survey data highlight a number of aspects that are not at all gratifying and which, in part, dispel the myth of the invincibility of the online academic teaching process. In this sense, on the one hand, the survey data reveal that the level of educational efficiency related to the online academic teaching process used during the pandemic period is not a high level (figure 1). In this sense, over $57 \%$ of the interviewed students consider that the online academic teaching process (used during the pandemic period) has a low educational efficiency.

Figure 1. Level of educational efficiency (online educational process)

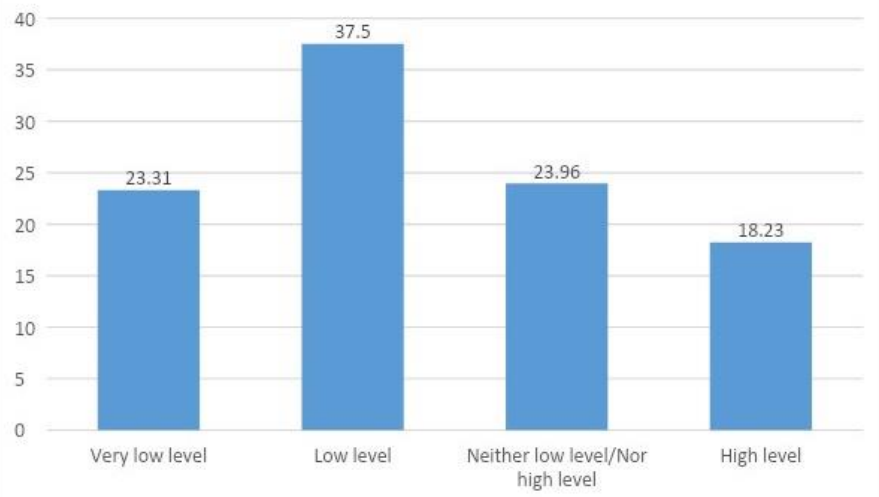

On the other hand, survey data reveal that, from a comparative point of view, the online educational process used is below the level of educational efficiency related to the classical (face-to-face) educational process. In this sense, practically more than $2 / 3$ of the interviewed students consider that the online educational process (and used in the pandemic period) is below the level of the classic educational process in terms of educational efficiency (figure no. 2).

Figure no. 2 Level of educational efficiency (online educational process compared to the classic educational process)

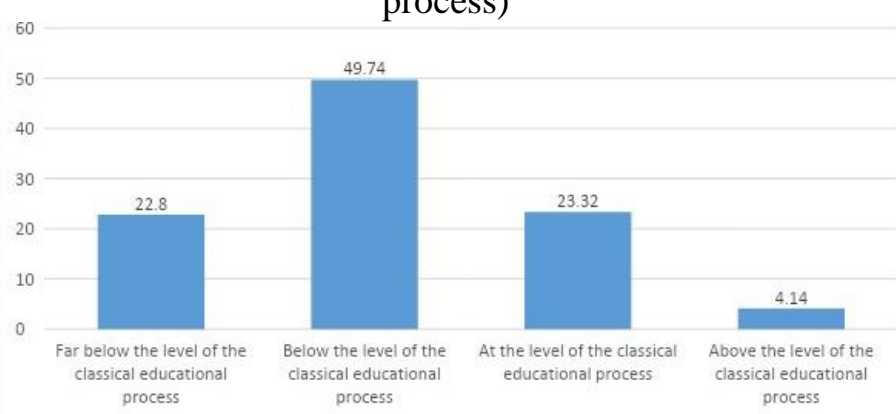

Last but not least, related to the educational efficiency related to the online teaching process used during the pandemic, the survey data reveal that there is a link between the level of study (the study program followed by the interviewee) and the perception of the level of efficiency. In this respect, the survey data reveal that the interviewed students following a bachelor's degree program consider the level of efficiency of the online educational process as much higher compared to the interviewed students following a master's program (Table no 3).

Table 3. Association table between the level of educational efficiency and the level of respondents' studies

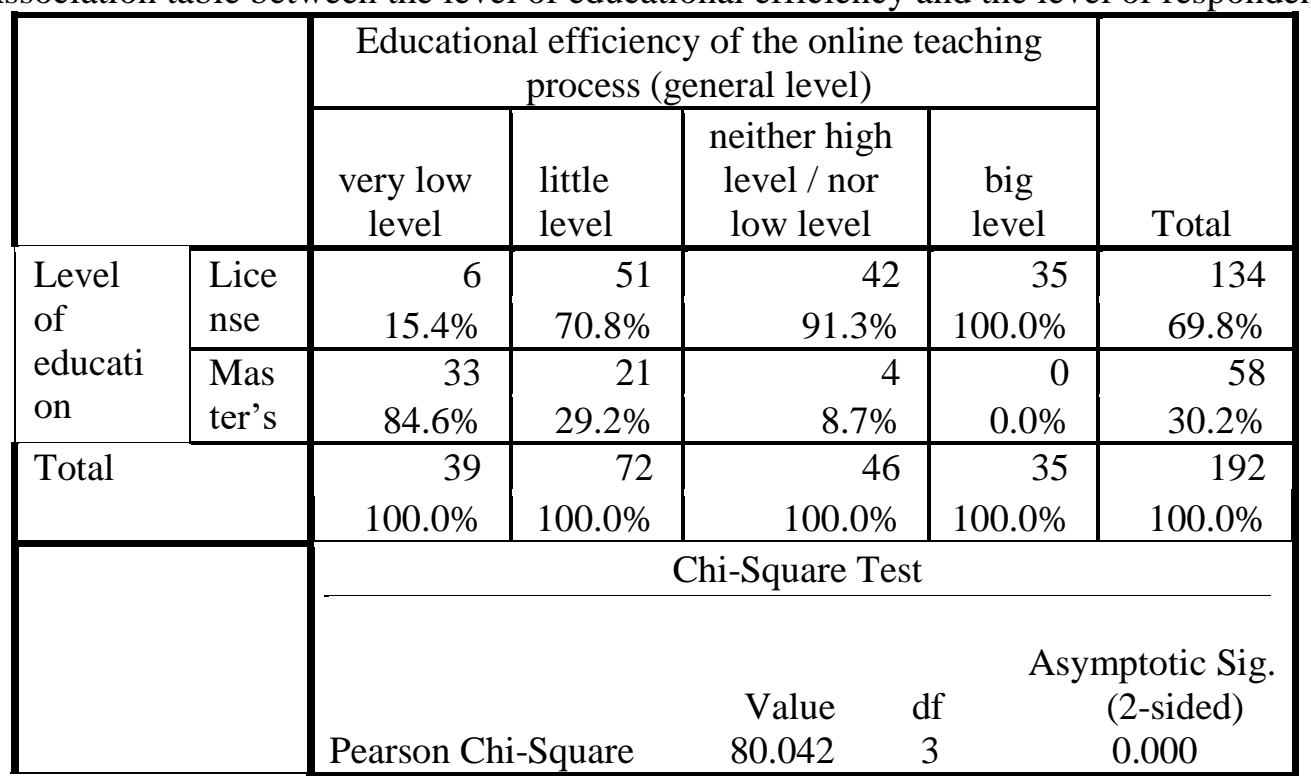

Regarding the factors that can negatively influence the online academic teaching process, the survey data reveals that there are at least 3 important factors that can influence the online teaching process (table no. 4). 
Table 4. The main factors influencing the online teaching process

\begin{tabular}{|c|c|c|}
\hline & $\begin{array}{l}\mathrm{Me} \\
\text { an }\end{array}$ & $\begin{array}{l}\text { Std. } \\
\text { Deviati } \\
\text { on }\end{array}$ \\
\hline $\begin{array}{l}\text { 1. Lack of (technical) resources } \\
\text { needed for the online teaching } \\
\text { process (example: internet access } \\
\text { and teaching platforms, webcams, } \\
\text { cloud storage, etc.) }\end{array}$ & 4.40 & .686 \\
\hline $\begin{array}{l}\text { 2. Lack of knowledge and technical } \\
\text { information held by students / } \\
\text { teachers on online teaching } \\
\text { platforms) }\end{array}$ & 4.17 & .814 \\
\hline $\begin{array}{l}\text { 3. Work and high individual work } \\
\text { (learning, homework preparation, } \\
\text { homework / project development) }\end{array}$ & 4.07 & .832 \\
\hline $\begin{array}{l}\text { 4. Resistance to change of students / } \\
\text { teachers (fear of something new } \\
\text { (scary) - feeling rejected by the new } \\
\text { because you think you can not cope } \\
\text { or may have negative effects or } \\
\text { repercussions for you) }\end{array}$ & 3.66 & .775 \\
\hline $\begin{array}{l}\text { 5. Communication in the interaction } \\
\text { between student teacher too low } \\
\text { compared to the classic teaching } \\
\text { process (face to face) }\end{array}$ & 3.53 & .913 \\
\hline $\begin{array}{l}\text { 6. Lack of support from the faculty } \\
\text { to encourage students to use ITC } \\
\text { tools and online platforms }\end{array}$ & 3.11 & 1.035 \\
\hline $\begin{array}{l}\text { 7. Lack of organizational measures } \\
\text { needed to run online courses through } \\
\text { platforms (planning courses and } \\
\text { seminars) }\end{array}$ & 3.09 & 1.151 \\
\hline $\begin{array}{l}\text { 8. Lack of clear documentation on } \\
\text { the use of online teaching platforms } \\
\text { (tutorials, user guides for Moodle } \\
\text { platforms, Zoom, WS Team, other } \\
\text { IT tools) }\end{array}$ & 2.96 & 1.154 \\
\hline $\begin{array}{l}\text { 9. Lack of training of students on the } \\
\text { use of online teaching platforms (or } \\
\text { other IT tools); }\end{array}$ & 2.84 & 1.083 \\
\hline
\end{tabular}

In this regard, it can be seen that the lack of resources needed for the online teaching process, as well as the lack of training on the use of different online teaching tools (lack of knowledge needed to use) can be considered as the factors that most negatively affect the online teaching process online teaching.

Another factor with a negative impact on the online academic teaching process, from the students' point of view, is the aspect related to the high volume of individual work that students have to submit as a result of the online academic teaching process. Basically, here we are talking about a perception of students about the work needed to be submitted for their academic training. Although surprising at first glance, the explanation for the emergence of this negative perception originates in one of the possible shortcomings of the online academic teaching process, namely due to the low level of teacher-student interaction compared to the classic teaching process). If for various reasons the process of online teaching leads to a low level of interaction between teacher and students inherently there is a change / shift (shift) of responsibilities in this educational process, namely: a decrease in teachers' responsibility to teach and an increase at the same time of the individual responsibility of the student to learn and prepare academically. Therefore, this increase in the volume of individual work required to be submitted by the student corresponds in essence to the increase in the individual responsibility for their academic training.

Last but not least, survey data reveal that we can identify other factors that negatively influence the online teaching process, although their effect is not as negative as the factors already mentioned. In this sense, like other factors that have a certain negative influence we can mention: the level of resistance to change of students / teachers, the level of reduced teacher-student interaction, respectively lack of support and stimulation for using ICT tools in the educational process.

\section{Conclusions}

Finally, the results showed that the online academic teaching process established during the pandemic is below the level of the classic teaching process, but from a certain point of view, the online teaching process, regardless of the forms and tools used, seems to be quite suitable in pandemic situations, especially when the situation requires the establishment of an epidemiological quarantine situation in the medium and long term. Undoubtedly, the use of this type of teaching during pandemics and implicitly during pandemic COVID-19 solves a big problem, namely: continuing the educational process (both in the medium and long term) while respecting the physical distance between people (rule of prevention on the spread of the pandemic). However, the use of the online teaching process during a pandemic requires, whether we like it or not, paying a price and it generates two big problems. In this sense, the price paid does not refer only to the expenses necessary for the development of the online educational process but also in terms of the level of educational efficiency. On the one hand, the costs of the online educational process are quite considerable and concern not only the acquisition of ICT tools (for example: laptops, webcams, online platforms, various video conferencing accounts) but also the costs related to training and preparation of the teachers and students.

For a number of educational institutions this expenditure cannot be borne as it is a major problem due to the lack of funds. On the other hand, the second price paid, respectively the second problem refers to the low level of educational efficiency that the online teaching process has, compared to the classic teaching process (face to face 
teacher students). From certain points of view, a low level of educational efficiency generates, sooner or later, a low level of quality of the educational process and which will ultimately have a negative impact on the specialized training of students. Because of this, the organization of the educational process only in the online environment I do not think is a viable option over time, respectively will have to find a way to alternate or combine the process of online teaching with the classic process (face to face).

Thus, when implementing an online academic teaching process, it must be borne in mind that there are a number of factors that can negatively affect this process, factors that we must take into account. In this sense, one of the factors necessary for successful implementation is, obviously, the allocation of resources both for the purchase of ICT equipment and tools specific to the online teaching process, and for the training of teachers and students. Last but not least, in order for the online teaching process to be successful, care must be taken in the emergence of the transfer of responsibility process: focusing on the teaching process on the individual learning process, a transfer that can lead inherently and implicitly to the increase of the degree of dissatisfaction.

Authors note: The authors have equal contributions to this article.

Horia Mihai Raboca is a senior lecturer at the Faculty of Political, Administrative and Communication Sciences (Babeș-Bolyai University, Cluj-Napoca), Department of Public Administration and Management. He graduated with a bachelor's degree in economics and a master's degree in public administration, obtaining the $\mathrm{PhD}$ in management. Research field of interest: evaluating the performance of public organizations and systems, measuring customer satisfaction of public institutions, education systems and public school. Among the main written articles are: "Determinants of customer satisfaction and service quality -the case of Romanian public services" and "ICT in education-exploratory analysis of students. Perceptions regarding ICT impact in the educational process".

Daniela Cotoranu is a $\mathrm{PhD}$ student at the Doctoral School of Administration and Public Policy, Faculty of Political, Administrative and Communication Sciences (BabeșBolyai University, Cluj-Napoca). She graduated with a bachelor's degree in public administration and a master's degree in human resources management in the public sector. Research field of interest: measuring the level of resilience in the public sector, life quality, evaluation of programs and projects, evaluation of the efficiency and performance of education systems. Her main article published is: "The Resilience of Civil Servants from the Romanian Rural Environment".
Adăscăliței, A. (2007). Instruire asistată de calculator: didactică informatică. Iași: Polirom Publishing House.

Amemado, D. (2020). COVID-19: An Unexpected and Unusual Driver to Online Education. The Global Picture. International Higher Education. Special Issue 2020.

Booker, D. (2000). Getting to grips with online delivery. Adelaide, South Australia: NCVER.

Brut, M. (2006). Instrumente pentru e-learning: ghidul informatic al profesorului modern. Iași: Polirom Publishing House.

Cho Y., Shim S.S. (2013). Predicting teachers' achievement goals for teaching: the role of perceived school structure and teachers sense of efficacy.Teaching and Teacher Education 32, 12-21.

Harper, B., Hedburg J., Bennett S., Lockyer L. (2000). The on-line experience: The state of Australian on-line education and training practices. Review of research. National Centre for Vocational Education Research.

Holt, M.E., Kleiber, P.B., Swenson, J.D., Rees, E.F. \& Milton, J. (1998). Facilitating group learning on the Internet. In Adult learning and the Internet, by Cahoon, B.Issue number 78. Jossey-Bass Publishers. San Francisco.

Hurlbut, A.R. (2018). Online vs traditional in teacher education: a comparison of student progress. American Journal of distance education, v. 32, no. 4, 248-266.

Hanushek, E. A. (1986). The Economics of Schooling: Production and Efficiency in Public Schools. Journal of Economic Literature, 23:1141-77.

Lockheed, M.E. \& Hanushek, E. (1994). Concepts of educational efficiency and effectiveness.Human Resources Development and Operations Policy. Working Paper Series.

Muilenburg, L.Y. \& Zane L. Berge (2007). Student barriers to online learning: A factor analytic study.Journal Distance Education, Vol.26, (1), 29-48.

Michie, M., (2020). Online Learning: The Future of Education. Available at: https://michaelkamau.academia.edu/ (Accessed at 16.09.2020).

Moise, G. (2008). Contribuţii la modelarea şi conducerea proceselor de instruire online utilizând tehnici de inteligență artificială.International Journal of Computers, Communications \& Control, 3 (1), 90102.University of Petroleum and Gas, Ploiesti.

Nikolaenko, V.S., Grakhova A., Rakhimov T. (2016). Improving the efficiency of the educational process using interactive teaching methods, SHS Web of Conferences 28(1):01073.

Dhull, I. \& Sakshi, M.S. (2017). Online learning.International Education and Research Journal, Vol. 3, No. 8.

Psacharopoulos, G. \& Loxley W. (1985). Diversified Secondary Education and Development: Evidence from

\section{References}


Colombia and Tanzania. Johns Hopkins University Press.

Radha, R., Mahalakshmi, K. Dr.V. Sathish Kumar, Dr.AR. Saravanakumar (2020). E-Learning during Lockdown of Covid-19 Pandemic: A Global Perspective.International Journal of Control and Automation, Vol. 13, No. 4, 1088-1099.

Raboca, H.M. (2006). Determinants of customer satisfaction and service quality - the case of Romanian public services.Transylvanian Review of Administrative Science, No.16E/2006, 124-135.

Raboca, H.M, Cărbunărean, F. (2014). ICT in educationexploratory analysis of students. Perceptions regarding ICT impact in the educational process.Managerial
Challenges of the Contemporary Society, Vol.7 (2), 5966.

Raboca, H.M., Cărbunărean, F. (2015). Students perception regarding the benefits and negatives of E-learning. Managerial Challenges of the Contemporary Society, Vol.8 (1), 134-140.

Sadeghi, R.,Moslehpour S. (2007). Comparison classical method of educational and modern web-based distance learning system (WBDLS). International Journal of Modern Engineering, Vol. 8 (1), 128-142.

Tamm, S. (2019). Disadvantage of E-Learning. Available at: https://e-student.org/disadvantages-of-elearning/ (Accessed at 15.09.2020).

https://education.stateuniversity.com (Accessed at 15.09.2020). 